\title{
Uses of medicinal plants in various diseases by the rural area of Uttaranchal region
}

\section{G. R. KISHORE}

ABSTRACT

The present survey focuses on the uses of medicinal plants in various diseases by the rurals of Uttaranchal region is selected as study area because it has rich heritage of medicinal plants. It contains so many rural areas. They cure various human diseases by medicianl plants.

Key words : Medicinal plants, Rurals, Uttranchal region

How to cite this paper : Kishore, G.R. (2016). Uses of medicinal plants in various diseases by the rural area of Uttaranchal region. Ann. Pharm. \& Pharm. Sci., 7 (1) : 25-28.

Article chronicle : Received : 27.11.2015; Revised : 13.03.2016; Accepted : 24.03.2016 